\title{
A CSALÁDOK OTTHONTEREMTÉSI KEDVEZMÉNYE ÉS ANNAK VÁRHATÓ HATÁSAI
}

\section{THE FAMILY HOUSING ALLOWANCE AND THE EFFECTS EXPECTED}

\author{
Tóth Flóra ${ }^{11}$ - Horváthné Dr. Kökény Annamária ${ }^{2}$ \\ ${ }^{1}$ Közgazdasági, Pénzügyi és Menedzsment Tanszék, Gazdálkodási kar, Neumann János \\ Egyetem, Magyarország, főiskolai hallgató \\ ${ }^{2}$ Közgazdasági, Pénzügyi és Menedzsment Tanszék, Gazdálkodási kar, Neumann János \\ Egyetem, Magyarország, főiskolai docens
}

\begin{abstract}
Kulcsszavak:
állami támogatás, lakhatás, pénzügyi kultúra, gyerekvállalás, biztonság
\end{abstract}

Keywords:

subsidy, housing, financial culture, raising children, safety

\section{Összefoglalás}

A gazdaság minden területén, épp úgy, mint az otthonteremtés esetében, fontos szerepet tölt be az állami szabályozás. Szükségességét az is mutatja, hogy a napjainkban elérhető és igényelhető Családok Otthonteremtési Kedvezménye (CSOK) egyre több család számára jelent fejlesztési lehetöséget, állami támogatás igénybevételével, egyre gyorsuló ügyintézés és egyre kedvezőbb feltételek megléte mellett. A CSOK témakörében szekunder kutatás mellett, primerkutatást is végeztünk, 2017 tavaszán és őszén a lakosság körében, mely eredményeinek bemutatására jelen cikk ad lehetőséget. Kérdőíves felmérést alkalmaztunk, melyben elsősorban a CSOK ismertségére, eddigi és várható eredményeire, hatásaira kerestük a választ.

\section{Abstract}

In every field of the economy, like housing, state regulations play an important role. The role of state regulations is shown by the Family Housing Allowance (CSOK) as a governmental influential tool, which means development for several families with a faster administration and with favourable terms. We used primary and secondary research as well to present our findings in this article. Our questionnaire-based survey primarily focuses on the examination of the acquaintance level of the CSOK among the Hungarian residents, the motivationial level to participate in the programme and the effects and the results of the CSOK.

\footnotetext{
1 Kapcsolattartó szerző. Tel.: +36 20/498-6073

E-mail cím: flora.toth93@gmail.com
} 


\section{Bevezetés}

A létbiztonságnak fontos szerepe van a családok életében, az otthonkialakításban. Az otthon adta biztonság egyik alappillére a család nagyságához, életéhez igazodó komfortos, saját tulajdonú lakás, ingatlan megléte, kialakítása. Már a kétezres években tapasztalható volt az építkezések tekintetében némi növekedés, mely a 2008-as válság következtében megtorpant. Ebből akár arra is következtethetünk, hogy a biztonságot jelentő otthonok kialakításának mértéke csökkent. Az önálló otthon, mint lételem tekintetében 2016 hozott jelentősebb változásokat a CSOK bevezetésének hatására. A ksh adatai szerint ez az év 9994 új ingatlan építését jelentette a támogatás kapcsán. Az állami támogatás hatására komfortos, jól felszerelt, magas energetikai besorolással rendelkező ingatlanok épülhetnek, melyek hozzájárulnak a a létbiztonság növekedéséhez, fenntartásához. A rendelkezésre álló adatok szerint az ingatlankialakítások a 2010-es években a magánszemélyekre, míg a 2016-os adatok szerint már nagyobb mértékben a vállalkozásokra voltak jellemzőek. A vissza nem térítendő támogatás keretében a bevezetésétől kezdődően több, mint 102 milliárd forintot költöttek otthonkialakításra, 2017-ben pedig ennek értéke a 210 milliárd forintot is meghaladta, mely jelentősen hozzájárul a megfelelő, stabil otthon kialakításához.[1][2] Cikkünkben azért választottuk a CSOK témakörét, mert egy olyan finanszírozási format szeretnénk bemutatni, mely hozzájárulhat a megfelelő, biztos otthon kialakításához azok esetében is, akik számára elérhetelennek tűnt a saját tulajdonú, bitonságos élettér létrehozása.

\section{Módszer}

Az otthonteremtési kedvezménnyel kapcsolatos kutatásunkat szekunder kutatással kezdtük, mely keretében a rendelkezésre álló jogszabályok, statisztikai jelentések, tanulmányok, szakcikkek kerültek feldolgozásra. Ezt követően primer kutatást végeztünk a háztartások körében, melyre 2017 őszén került sor egy korábbi felmérés adatainak kiegészítése céljából. Online elkészített kérdőív segítségével történt az adatgyüjtés, mely kiegészült papír alapon történő megkérdezéssel a lehető legszélesebb érdekcsoporthoz való eljutás érdekében. Az első kérdőívet 537 háztartás töltötte ki, míg a jelenlegi kutatásunk során 631 válasz szerepel. A vizsgálatok során a CSOK ismertsége mellett az eddig elért eredményekre és a várható hatásokra, jövőbeli elképzelésekre kerestük a választ.

\section{Tárgyalás}

\subsection{A CSOK bemutatása}

Minden otthonkialakítás, gyermekvállalás előtt álló család esetében felmerül az a kérdés, hogy is kezdjenek neki, hogy tudják ezt finanszírozni, elérhető-e valami támogatás a költségcsökkentés céljából. Már a kérdések felvetése során megmutatkozik az, hogy szükség lehet állami szabályozásra az otthonteremtés kapcsán, a biztonságra a lakhatásban. Jelenleg ennek képviselője a CSOK, mely 2015-óta érhető el az otthonkialakítás, illetve átalakítás előtt álló gyermekes és/vagy gyermeket vállaló családok számára. A bevezetése óta már számos családnak jelentett, illetve jelent segítséget a támogatás igénybevétele, és egyre növekvő tendenciát mutat, így ösztönözve a jövőbeli támogatással élőket is. Az igénylések mértékének növekedése 2017-re számos bank esetében a 40 százalékos növekedést is meghaladta a 2016os értékekhez mérten. Az OTP Bank esetében 46 százalékos igénylésnövekedést tapasztaltak a megelőző időszakhoz képest, 93000 elfogadott és minimális számú elutasított kérelem mellett.[3]

A CSOK nem más, mint egy olyan állami támogatási forma, melyet a gyermeket nevelő és gyermeket vállaló szülők megsegítésére hoztak létre. 2015 júliusa óta érhető el. A 17/2016 (II.10) kormányrendelet $1 . \S$-a szerint a nagykorú gyermeket nevelő vagy gyermeket vállaló személyek vissza nem térítendő állami támogatásban részesülhetnek a meghatározott feltételek maradéktalan teljesítése mellett, melyet a Magyar Államkincstár a család által 
választott hitelintézeten keresztül bonyolít le. Maga a kedvezmény kizárólag lakás vásárlására (használt, új), bővítésére, építésére használható fel. A fogalom meghatározása esetén fontos megjegyezni azt, hogy egy gyermek/gyermekek után kizárólag egy alkalommal lehet a támogatást igénybe venni.[4]

A program feladata az otthonteremtés mellett, hogy pozitív hatást gyakoroljon a gyermekvállalási kedvre, emellett az építőiparra, valamint az ingatlanpiacra gyakorolt növekedést ösztönző hatása sem elhanyagolható. A növekedést az ingatlanpiac esetében a Központi Statisztikai Hivatal adatai is szemléltetik. A KSH adatai szerint 2017 harmadik negyedévében több mint, 12\%-os növekedés volt tapasztalható az egy évvel korábbi adatokhoz képest az ingatlanpiacon. A használt ingatlanok esetében szintén növekedés jelentkezett, mely adatok mind az iparág erősödésére utalnak.[5]

$\mathrm{Az}$ igényelhető összeg mértéke több tényező együttes hatásától függ. Az egyik meghatározó tényező a gyermekek száma, ugyanis a legmagasabb összeg eléréséhez minimum három, a meghatározott feltételek közé sorolható gyermekből kell, hogy álljon a család. Nem elhanyagolható tényező a kedvezmény típusának meghatározása sem, hiszen a maximális összeg kizárólag új lakás vásárlása vagy építés mellett érhető el, míg bővítés és használt ingatlan vásárlása esetén a legnagyobb odaítélhető összeg háromnál több gyermek esetén sem érheti el a 10 millió forintot.

Az odaítélhető/megkapható összegeket az 1. számú táblázat foglalja össze, amely a 17/2016 (II.10.) és a 16/2016. (II. 10.) kormányrendeletet alapul véve készült, melyek egyértelműen meghatározzák a gyermekek számától függően az egyes kategóriákban a maximálisan megkapható összegeket. Abban az esetben, ha a kedvezmény igénylője új lakás vásárlását, építését határozza el, az igényelhető összeg mértéke három csoportba sorolható. Az első kategóriát az egy gyermek vállalása melletti igénylők képviselik, az ő esetükben maximum 600.000 forintos támogatás kapható a vásárlásra vagy az építésre. Két gyermek esetén ez az összeg már a korábbi többszöröse, melynek legnagyobb értéke 2.600.ooo forint. Mivel egy családtámogatási formáról van szó, így a maximálisan igényelhető összeget a nagycsaládosoknak teszik elérhetővé, vagyis a minimum három gyermeket vállalt családoknak. Náluk az igényelhető és lakáscélra felhasználható támogatás akár a 10.000.000 forintot is elérheti, sőt lehetőség van további maximum 10.000.00o forint kedvezményes hitel felvételére, természetesen a megfelelő feltételek megléte mellett. Új ingatlan esetén az általános forgalmi adó visszaigénylésére is lehetőség nyílik. A számlával igazolt teljesített szolgáltatások esetében 5.000 .000 forintos felső határ mellett áfa visszaigénylésére van lehetősége a CSOK összegét felhasználó családoknak.[6]

1. Táblázat. A CSOK összege a gyermekek számától függően

\begin{tabular}{|cccc|}
\hline \multicolumn{2}{|c|}{ Új lakás vásáurlása/építése } & Haszmált lakás vásáurlása/meglévö bövítése \\
\hline Egy gyermek & $600.000 \mathrm{Ft}$ & Egy gyermek & $600.00 \mathrm{Ft}$ \\
\hline Két gyermek & $2.600 .000 \mathrm{Ft}$ & Két gyermek & $1.430 .000 \mathrm{Ft}$ \\
\hline $\begin{array}{c}\text { Három vagy több } \\
\text { gyermek }\end{array}$ & $10.000 .000 \mathrm{Ft}$ & Három gyermek & $2.200 .000 \mathrm{Ft}$ \\
\hline & & Háromnál több gyermek & $2.750 .000 \mathrm{Ft}$ \\
\hline
\end{tabular}

Forrás: 17/2016. (II. 10.) Korm. rendelet, 16/2016. (II. 1O.) Korm. rendelet alapján

saját szerkesztés, Letöltés dátuma: 2018.01.15. 
Használt lakás vásárlása és a meglévő bővítése esetén is, már jóval kisebb igénybe vehető támogatási összegekről beszélhetünk, mint teljesen új ingatlan esetén. A családok számára megkapható összeg természetesen itt is szoros összefüggésben van a gyermekek számával. Ebben az esetben négy kategória kerül kormányrendeleti szinten elkülönítésreA legmagasabb elérhető összeg három gyermeket meghaladóan 2.750.000 forint, amely használt ingatlan vételére, illetve a korábban is említett saját tulajdonú ingatlan bővítésére fordítható. [7]

A megelőlegezett CSOK egy igen előnyös konstrukciónak bizonyul abban az esetben, amennyiben a fiatal házaspárok gyermekvállalás mellett döntenek, ha még nincs gyermekük, vagy további gyermeket, gyermekeket vállalnának a meglévőek mellé. A támogatás előnye abban rejlik, hogy meghatározott időn belül vállalt maximum két gyermek esetén igényelhető a lakáscélú vissza nem térítendő állami támogatás. Magára a gyermekvállalásra egységesen 4 év az első, 8 év halasztó határidő pedig a második gyermekre vonatkozik. Legfeljebb két gyermek születését lehet bevállalni. Fontos ennek kapcsán megjegyezni azt, hogy az örökbefogadás is teljes értékü gyermekvállalásnak minősül, tehát a támogatási összeg ezen formában is igénybe vehető. Amennyiben a rendeletben meghatározott esetek állnak fenn, vagyis a gyermekvállalás nem teljesül a felsorolt indokok valamelyikével összefüggésben, abban az esetben a kedvezmény visszafizetésére kerülhet sor a meghatározott módón és ütemezésben.[8] [9]

A CSOK 2015-ös elérhetősége óta számos változtatást, pontosítást hajtottak végre. Ezek közül a leginkább említésre méltóak- melyek mai napig az irányadóak- a 2016-ban történt módosítások. Ebben az évben került elfogadására és bevezetésre, a 17/2016. (II. 10.), illetve a 16/2016. (II. 10.) kormányrendelet, amik a CSOK jelenleg érvényes szabályozásait mutatják be, a használt ingatlan beszerzésével, meglévő ingatlan bővítésével, valamint az új ingatlan építésével vagy vásárlásával összefüggésben.[10]

Használt ingatlanok esetén a négyzetmétersávok eltörlésre kerültek, tehát a támogatás összege egy minimális négyzetméterszint elérése mellett igényelhető és összege nem függ az ingatlan hasznos alapterületének nagyságától. Egységesen a legmagasabb összeget tették maximum elérhetővé a családok számára, így használt lakás esetén 1 gyermekre 600.00o forint, 2 gyermekre 1.430.00o forint, 3 gyermekre 2.200.000 forint, négy vagy több gyermekre pedig 2.750.00o forint igényelhető.[11]

2016-os évben enyhítették a vállalt gyermekre érvényes feltételek életkorra való részét, mely szerint megelőlegezett CSOK esetén elegendő, ha csak az egyik szülő 40 év alatti. Továbbá a felsőoktatásban nappali tagozaton tanuló gyermek esetén 25 éves korig, illetve tovább nem nappali tagozaton vagy nem tovább tanuló gyermek 20 éves korig képezheti az igénylés alanyát.[12] [13] Az előző évekhez hasonlóan 2017-re további változtatásokat eredményeztek a program felülvizsgálatai, könnyítve az igénylés megvalósulását.

\subsubsection{8-ban várható változások a családokra nézve}

2018 februárjától, illetve januárjától több változtatást is kezdeményezett a kormány, mely a jelzáloghitelek és a CSOK rendszerét is érinti a gyermeket nevelő, vállaló családok szempontjából. 2018 február elejétől az otthonteremtési támogatás kedvezóbb feltételekkel érhető el. A változtatások elsősorban az igénylés bonyolultságának csökkentését célozták, mely jó hír lehet azon családok számára, akiket a program bonyolultsága tántorított el eddig a támogatás igénybevételétől. Az állami szabályozás célja, hogy az igénylési folyamat egyszerübb legyen, és az adminisztratív terhek is mérséklődjenek. Vélhetően változik az egyes igénylési kategóriák összegéhez tartozó minimum érték is. 
A családok gyermekvállalásának ösztönzésére és a CSOK igénybevétele mellett történő jelzáloghitellel történő kiegészítésre hiteltörlesztési támogatási formát tesz elérhetővé az állam 2018 január elsejét követően. A 337/2017. (XI. 14.) kormányrendelet meghatározza, hogy mely esetekben jogosultak a családok a hitelcsökkentés igénybevételére. A rendelet alapján a harmadik és minden további gyermek esetén, akik 2018 január elseje után születnek, egymillió forint értékű vissza nem térítendő támogatás jár a háztartás lakáscélú jelzáloghitel tőketartozása után, azaz a meglévő tőketartozást csökkentik az egy millió forintos támogatással. Kezdetben a CSOK által elérhető kedvezményes hitel nem tartozott a kiváltható hitelek közé, azonban a döntéshozók arra a megállapodásra jutottak, hogy a gyermekvállalás ösztönzése érdekében egyik érdekcsoport sem maradhat ki az állam által nyújtott támogatásból, mely egyaránt hosszú távú érdekét képviseli a magyar társadalomnak.[14] [15]

\section{Eredmények}

\subsection{Primer kutatás}

A CSOK témája kapcsán két alkalommal végeztünk kérdőíves megkérdezést, 2017 tavaszán és őszén. Jelen cikkünk az őszi kutatás részeredményeinek bemutatására szolgál.

A 2017 őszén történő felmérésben 631 háztartás vett részt, kitöltésével segítve a minél pontosabb eredmények elérését. Választ kaptunk arra, hogy a kutatásban részt vevő háztartások éltek-e már a támogatás adta lehetőséggel, milyen célra használták fel, valamint hogy azok a családok, akik eddig nem igényelték a CSOK-ot, milyen jövőbeni célokat valósítanak meg a kezdeményezés elérhetősége alatt.

A válaszok vizsgálatát követően megállapítható, hogy a háztartások több mint, 99 százaléka (625 háztartás) találkozott már a támogatással valamilyen formában annak bevezetése óta. Az adatokból látható, hogy a kitöltők 28 százaléka (174 háztartás) igényelte már a CSOK-ot. A korábban végzett kutatásunk esetében az igénylők aránya 22 százalékot (118 háztartás) tesz ki. A két időszak adatát összevetve az igénylések számában és arányában egyaránt növekedés tapasztalható, mely a program eredményességét, a benne rejlő további lehetőségekre enged következtetni.

A 174 háztartás közül megállapítható, hogy 33 százalékuk (57 háztartás) új ingatlan építése mellett, 45 százalékuk (78 háztartás) használt ingatlan vásárlása mellett döntött, a fennmaradó 22 százalék (39 háztartás) pedig a bővítés valamint az új ingatlan vásárlási kategória között oszlik meg. Ez alapján is látható az, hogy a CSOK ösztönzően hathat az építőiparra és ingatlanpiacra a mintában megállapított növekvő igényeknek köszönhetően.

A támogatás által az igénylő háztartások kisebb-nagyobb mértékủ állami segítségben részesültek, melynek megoszlásának vizsgálatát is célul tűztük ki. Az igénylő háztartások 46 százaléka (80 háztartás) 5 és 10 millió forint közötti összegű támogatásban részesült, mely jelentős segítségnek bizonyult az építkezések és az új lakások vásárlásánál egyaránt. További 19 százalék (33 háztartás) esetén 1,5 millió forint és 2,6 millió forint közötti támogatásban részesültek a háztartások, mely nem alkalmas a célok teljes körü finanszírozására, viszont a terhek csökkentésének jelentős elemét képezi. Tehát a támogatás összegével kapcsolatban elmondható, hogy az odaítélt támogatások - legyen szó vásárlásról, bővítésről vagy építkezésről - jelentősen csökkenthetik a háztartásokat érintő terheket, ezáltal biztosítva a megfelelő otthon kialakítását.

Fontosnak tartottuk annak megismerését is, hogy a háztartások miként tudnak eligazodni a pénzügyi világban. Ennek kapcsán vizsgáltuk a válaszadók és a CSOK szabályozások viszonyát, az igénylési feltételek ismertségét, amelyet az 1. ábra szemléltet. 
1. ábra. Mennyire ismeri a CSOK igénylésének feltételeit?

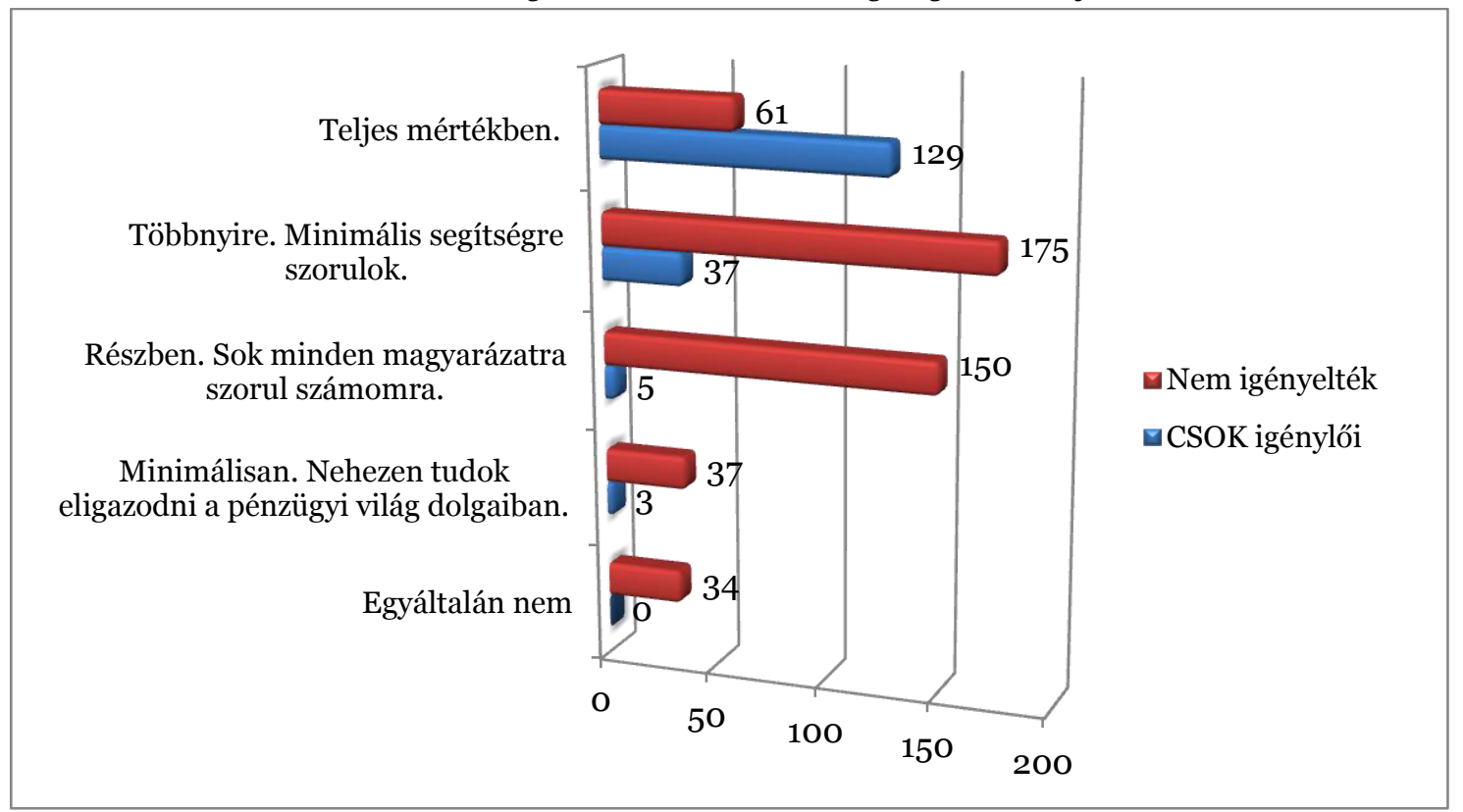

Forrás: Saját kutatás alapján, saját szerkesztés, $N=631$ háztartás

A grafikonon a támogatás ismertségére vonatkozó adatok két vetületben jelennek meg. A diagram egyik része azt jeleníti meg, hogy a CSOK igénylői körében mennyire ismert a támogatás (174 háztartás). A másik vetület azt ábrázolja, hogy a program lehetőségeit eddig nem használó háztartások mennyire ismerik a támogatás jellemzőit (457 háztartás). Megállapítható az a tendencia a mintánk alapján, hogy az igénylők esetében legalább minimális ismertséggel rendelkeznek a háztartások, mely azért tekinthető pozitív eredménynek, mert az otthonkialakítás során feltételezhetően előre tervezett, jól megalapozott döntéseket hozva valósították meg céljaikat. Szintén kedvező eredménynek tekinthető, hogy a támogatást teljes mértékben ismerők 64 százaléka (129 háztartás) a kezdeményezés igénylői közé sorolhatóak. Figyelemre méltó az az adat is, hogy a támogatást egyáltalán nem ismerők, valamint a minimális ismeretekkel rendelkezők a vizsgált válaszok 12 százalékát (74 háztartás) adják. Náluk véleményünk szerint az ismeretek hiányát az okozhatja, hogy nem tartoznak a jogosultak, azaz a későbbi igénylők körébe, így nincs szükségük a terület kapcsán az ismereteik bővítésére. Tehát összességében az látható, hogy mind a támogatást igénylők, mind az azzal nem élők esetében is, hogy többségében magyarázat és minimális segítség mellett képesek lehetnek értelmezni a támogatás adta lehetőségeket, annak menetét, valamint az igényléshez szükséges feltételeket.

Az 1. ábra rávilágít arra, hogy ahhoz, hogy a Családok Otthonteremtési Kedvezményén keresztül elérhesse a célját, nem csak a háztartások megfelelő körét kell elérnie, hanem a megfelelő pénzügyi szemlélet megléte, kialakítása is elengedhetetlen. Számos korábbi kutatás rávilágít arra, hogy a pénzügyi kultúra fejlesztését már gimnazisták, szakközépiskolába járók esetében is fejleszteni kellene, továbbá ezt a kérdést kiemelten kell kezelni a felnőtt lakosság esetében is.[16] [17] [18] [19]

A korábbi kutatásunkat alapul véve, az őszi felmérés során is vizsgáltuk azt, hogy a CSOK által kínált lehetőséggel eddig nem élők terveznek-e jövőbeni igénylést, és ha a nemleges válasz mellett döntenek, annak mi lehet a fő oka.[20] 
2. ábra Ha még nem igényelte, a későbbiekben tervezi-e igényelni?

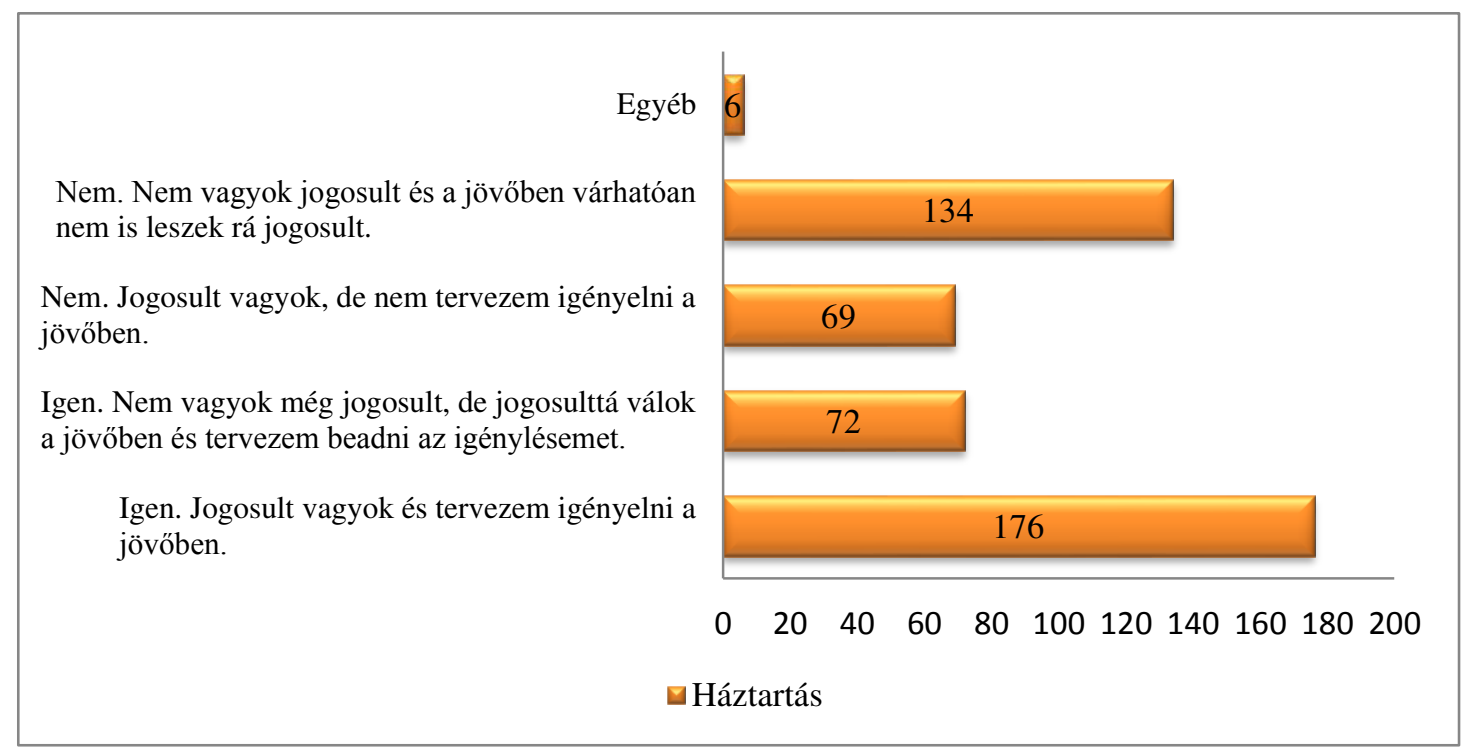

Forrás: Saját kutatás alapján, saját szerkesztés, $N=457$ háztartás

A CSOK, mint vissza nem térítendő támogatás várható hatásainak vizsgálatának része, hogy a jövőbeni várható igényléseket is vizsgáljuk. Ezt a 2. ábránkon keresztül szemléltetjük. A diagramon látható, hogy a jövőbeni igénylések várhatóan, a támogatást eddig nem igénylő háztartások 54 százalékát (248 háztartás) érintik. A fennmaradó 46 százalék (209 háztartás) esetében olyan háztartások jelennek meg, akik vélhetően nem fognak élni az otthonteremtési támogatással, ezért esetükben vizsgáltuk ennek az okát. A további vizsgálat alapján megállapíthatjuk, hogy feltételezhetően az igénylések elmaradásának legfóbb oka a háztartások hitelképtelensége, valamint az ügyintézés bonyolultsága. A bonyolultság csökkentését szolgálja a 2018 februári szabályozásmódosítás, amely szükségességét a kutatásunk is alátámasztja. Az igénylés menetének bonyolultságának csökkentésével, növekedhet az igénylők köre is.[21]

A kérdőíves felmérésünk során, mindkét alkalommal jelentős szempont volt a gyermekvállalási hajlandóság vizsgálata, hiszen annak növekedése az állam hosszú távú terveinek részét képezi. Primer kutatásaink során azt tapasztaltuk, hogy a megkérdezettek közül 144 háztartás,[20] illetve 159 háztartás vállalna gyermeket annak érdekében, hogy részesülhessenek a CSOK kínálta lehetőségekben. Továbbá a támogatás eddigi igénylői közül 50 válaszadó további gyermek vállalása mellett döntött, hogy a lehetőségeikhez mérten maximálisan ki tudják használni a kezdeményezés lehetőségeit. Tehát látható az, hogy minimálisan, de növekedett, és növekedhet a társadalom egészét tekintve a gyermekvállalási hajlandóság, mely egyaránt pozitív hatást gyakorolhat mind a társadalomra mind az államháztartásra.

\subsection{Következtetések}

A kérdőíves felméréseink alapján is feltételezhető, hogy egyre ismertebbé és népszerübbé válik a Családok Otthonteremtési Kedvezménye a háztartások körében, amely egyre több család biztonságát erősíti, a saját tulajdonú ingatlanhoz jutáson keresztül. A családok érdekeit figyelembe véve további pozitív hatásokra számíthatunk a támogatás kapcsán és az otthonkialakítások során, melyet a jövőbeli várható igénylések száma is jelezni fog. A kezdeményezés gazdaságélénkítő hatással bírhat, melyet az ingatlanpiac, építőipar fellendülése valamint a gyermekvállalási kedv növekedése is igazolhat. A kutatásunk alapján 
tehát feltételezhető, hogy az állami szabályozásnak elengedhetetlen szerepe lehet abban, hogy a gazdaság és a társadalom a jelenlegi szint fölé emelkedhessen, biztosítva a családok egyre nagyobb biztonságát.

\section{Köszönetnyilvánítás}

Köszönettel tartozunk a kutatás támogatásáért, amely az EFOP-3.6.1-16-2016-00006 „A kutatási potenciál fejlesztése és bővítése a Neumann János Egyetemen” pályázat keretében valósult meg. A projekt a Magyar Állam és az Európai Unió támogatásával, az Európai Szociális Alap társfinanszírozásával, a Széchenyi 2020 program keretében valósul meg.

Köszönettel tartozunk az Emberi Erőforrások Minisztériuma által az Új Nemzeti Kiválóság Program keretében meghirdetett (ÚNKP-17-1) Felsőoktatási Alapképzés Hallgatói Kutatói Ösztöndíj 2017/2018. tanévre nyújtott kutatási támogatásáért (ÚNKP-17-A-PAE-27).

\section{Irodalomjegyzék}

[1] KSH: http://www.ksh.hu/docs/hun/xftp/idoszaki/mo/mo2016.pdf [Megtekintés: 2017-1220.]

[2] BankWeb: https://www.bankweb.hu/csok-statisztika-johet-java/ [Megtekintés: 2017-12-20.]

[3] Origo:http://www.origo.hu/gazdasag/20171115-megnott-a-csok-folyositas-2017-ben.html [Megtekintés: 2017-12-20.]

[4] 17/2016. (II. 10.) Korm. rendelet a használt lakás vásárlásához, bővítéséhez igényelhető családi otthonteremtési kedvezményről, $1 \S, 4 \S$

[5] HVG:http://hvg.hu/gazdasag/20180129_Eros_fordulat_a_hasznaltlakaspiacon_negy_evvel_ ezelott_tortent_ilyen_utoljara [Megtekintés: 2017-12-20]

[6] 16/2016. (II. 10.) Korm. rendelet az új lakások építéséhez, vásárlásához kapcsolódó lakáscélú támogatásról 9§,69§

[7] 17/2016. (II. 10.) Korm. rendelet a használt lakás vásárlásához, bővítéséhez igényelhető családi otthonteremtési kedvezményről $11 \S$

[8] 17/2016. (II. 10.) Korm. rendelet a használt lakás vásárlásához, bővítéséhez igényelhető családi otthonteremtési kedvezményról $20 \S$

[9] 16/2016. (II. 10.) Korm. rendelet az új lakások építéséhez, vásárlásához kapcsolódó lakáscélú támogatásról $34 \S$

[10]16/2016. (II. 10.) Korm. rendelet az új lakások építéséhez, vásárlásához kapcsolódó lakáscélú támogatásról

[11] 17/2016. (II. 10.) Korm. rendelet a használt lakás vásárlásához, bővítéséhez igényelhető családi otthonteremtési kedvezményről $8 \S, 11 \S$

[12]16/2016. (II. 10.) Korm. rendelet az új lakások építéséhez, vásárlásához kapcsolódó lakáscélú támogatásról

[13]17/2016. (II. 10.) Korm. rendelet a használt lakás vásárlásához, bővítéséhez igényelhető családi otthonteremtési kedvezményről

[14]337/2017. (XI. 14.) Korm. rendelet a három- vagy többgyermekes családok lakáscélú jelzáloghitel-tartozásainak csökkentéséről

[15]Világgazdaság: https://www.vg.hu/gazdasag/nagycsaladosoknak-kedvezo-kormanyrendeletjelent-meg-679735/ [Megtekintés: 2017-12-20]

[16]Horváthné Kökény A. (2014): Az állami szabályozás hatása a lakosság hosszú távú megtakarításaira, Disszertáció, 272 p. 
[17]Zsótér B. - Béres D. - Németh E. (2015): A Magyar fiatalok jellemzése pénzügyi attitűdjei és magatartásuk mentén: Vizsgálat a felsőoktatában tanulók pénzügyi attitüdjeiról és magatartásáról. Vezetéstudomány, 46 (6). 70-80 pp.

[18]Béres D. - Huzdik K. (2012): A pénzügyi kultúra megjelenése makrogazdasági szinten, Pénzügyi Szemle, 2012/3. szám, 322 - 336 pp.

[19]Botos K. - Botos J. - Béres D. - Csernák J. - Németh E. (2012): Pénzügyi kultúra és kockázatvállalás a közép-alföldi háztartásokban, Pénzügyi szemle, 2012/3. szám, 291-309 pp.

[20] Horváthné Dr. Kökény Annamária - Tóth Flóra (2017): A Családok otthonteremtési kedvezménye a családok szemszögéből, GRADUS 4:(2). 528-533 pp.

[21]HVG:http://hvg.hu/gazdasag/20180119_egyszerusitik_a_csok_igenyleset_de_meg_nem_ar uljak_el_hogyan [Megtekintés:2017-12-20] 